\title{
Walkability and Fitness Center Prices, Opening Hours, and Extra Services: The Case of Madrid, Spain
}

\author{
Jairo León-Quismondo *®e, José Bonal@, Pablo Burillo and Álvaro Fernández-Luna \\ Faculty of Sports Sciences, Universidad Europea de Madrid, Calle Tajo S/N, Villaviciosa de Odón, 28670 Madrid, \\ Spain; jose.bonal@universidadeuropea.es (J.B.); pablo.burillo@universidadeuropea.es (P.B.); \\ alvaro.fernandez2@universidadeuropea.es (Á.F.-L.) \\ * Correspondence: jairo.leon@universidadeuropea.es; Tel.: +34-912-113-505
}

Received: 9 July 2020; Accepted: 3 August 2020; Published: 4 August 2020

\begin{abstract}
Walkability has been associated with urban development and political plans, contributing to more connected cities with improvements in communication, shopping, and pedestrian base. Among these services, fitness centers are becoming important elements for communities due to their impact on the health and welfare of citizens. The present study aims to examine how an area's Walk Score ${ }^{\circledR}$ affects fitness center services, specifically membership costs, opening hours, and aquatic services. Data from 193 fitness centers were retrieved, representing all the areas of the municipality of Madrid, Spain, including fitness centers in the 21 city districts. A nonlinear relationship between an area's Walk Score ${ }^{\circledR}$ and fitness centers' monthly fees is observed. Only in premium fitness centers, a weak curvilinear model is observed, following a quadratic equation, showing that fitness centers with higher prices are in less walkable areas. Additionally, the association between Walk Score ${ }^{\circledR}$ and a fitness center's opening hours reveals that fitness centers with wider hours of operation tend to be in moderately to highly walkable locations. Lastly, the existence of a swimming pool is related to a lower Walk Score ${ }^{\circledR}$. Thus, fitness centers in less walkable areas try to offer additional services as differentiation from competitors, whereas centers in walkable locations use this advantage as a strength.
\end{abstract}

Keywords: walkability; fitness centers; services; urban environment

\section{Introduction}

The concept of walkability is defined as "the extent to which the built environment is friendly to people who walk to work, for leisure or recreation, to travel, for exercise, or to access services" [1]. Overall, it can be broadly understood as the extent to which an area, usually an urban area, is walking-friendly [2]. Proven benefits of living in walkable environments include a healthier lifestyle [3,4] and less polluted and congested streets [5,6] as well as economic benefits [7]. This evidence has led to an increase in research on the design of walkable cities [1]. Following previous work, there are some urban elements that are central for walkability. These are the connectivity of the path network, linkage with other modes of transport (bus, subway, or train), safety from both traffic and social crime, quality of path (width, paving, or signing) and path context (street design, visual interest, or landscape), and varied land use patterns (reaching most local services on foot within 10-20 min, including uses such as shops, cafes, banks, laundries, grocery stores, parks, or fitness centers) [5]. Thus, walkability is tightly associated with urban development and political plans, contributing to a more connected city with improvements in communication, services, shopping, and pedestrian base [8].

City services have been widely analyzed in recent years in relation to the concept of smart cities [9], user information and communication technologies [10], and the habits of individuals based on their relationship with the environment [11,12]. Among the different approaches, it is not easy to find a 
variable to measure the quality of life of citizens tightly related to the services that cities offer-with the exception of satisfaction surveys and consumption habits. Different perspectives on walkability also lead to diverse focuses [13]. Consequently, a wide range of quantitative and qualitative tools have been used to assess the walkability of urban environments. Some examples are the Pedestrian Environment Review System (PERS), Pedestrian Level of Service (POS), or Geographic Information Systems (GIS). In view of the range of studies, diverse issues in measuring walkability have also emerged $[14,15]$, including trip purpose, temporal issues (different times of day), walking barriers, and the perceived quality of walkable spaces. These issues highlight the difficulties in assessing walkability. In this regard, following Vale et al. [15], there are four main methodological categories for assessing walking accessibility: distance-based, gravity-based, topological or infrastructure-based, and walkability or walk score-type. This research focuses on this last approach.

Since its creation in 2007, Walk Score ${ }^{\circledR}$ has been one of the most widely used methods worldwide for walkability assessment. Walk Score ${ }^{\circledR}$ is a United States-based company that provides walkability services and apartment search tools through a website and mobile applications. Walk Score ${ }^{\circledR}$ uses data provided by the Google ${ }^{\mathrm{TM}}$ AJAX Search application program interface (API) through a geography-based algorithm [16]. The Walk Score ${ }^{\circledR}$ algorithm calculates a score of walkability based on the distance to 13 categories of amenities (grocery stores, coffee shops, restaurants, bars, movie theaters, schools, parks, libraries, book stores, fitness centers, drug stores, hardware stores, clothing/music stores). Each category is weighted equally, and points are summed and normalized to yield a score of 0-100 [17].

The score has been validated by the scientific literature as a reliable way to measure access to walkable amenities mainly in the United States $[18,19]$, and its use is being extended to other regions, including Europe $[14,20,21]$ and Asia $[22,23]$. However, some researchers claim that Walk Score ${ }^{\circledR}$ and other applications do not replace conventional street network measures but are complementary [24]. A recent systematic review indicates that the analysis of walkability using Walk Score ${ }^{\circledR}$ is inconsistent due to research results tending to only partly support the validity of Walk Score ${ }^{\circledR}$ [2]. Despite the criticism, the research community considers that there is no reason to believe that Walk Score ${ }^{\circledR}$ is substantially different than in the United States-based studies $[20,21]$, and it is valid in high population density urban areas [19].

In addition, Walk Score ${ }^{\circledR}$ has been used in the scientific literature to evaluate physical activity, health status, and sedentary behavior $[20,25,26]$, tourism accommodation and services [14,23], eating habits [27], and walking and gaming mobile apps use [28]. Nevertheless, there is no specific research about Walk Score ${ }^{\circledR}$ and fitness centers, considering that gyms and sports centers are part of the Walk Score ${ }^{\circledR}$ algorithm. This knowledge gap in the literature regarding fitness centers should be addressed, since these sports services are fundamental for active lifestyle promotion and have important impacts on health $[29,30]$. Furthermore, it is difficult to find previous research that links Walk Score ${ }^{\circledR}$ with important service variables such as price and opening hours. As an example, other authors have found how Walk Score ${ }^{\circledR}$ could affect pricing in other tourist services [23]. For that reason, this paper tries to answer the research question: "How does location affect fitness center services?".

In this vein, several authors have raised the importance of the evaluation of fitness services, meaning a detailed analysis of the provided service that contributes to making managerial actions more precise. Additionally, authors have examined specific business models based on price [31] or the analysis of the importance and performance of different services and management decisions [32]. For this purpose, after the literature review, a possible relationship between the Walk Score ${ }^{\circledR}$ and different variables such as prices, opening hours, and specific services at fitness centers is considered, depending on the city district and its walkability. Traditionally, price has been identified as one of the main reasons to enroll in a fitness center [32]. Moreover, opening hours are crucial, even more so in a big urban area such as a capital city. Additionally, extra services such as aquatic services contribute to attracting more people to the centers. Thus, this study aims to examine how the location, measured by Walk Score ${ }^{\circledR}$, affects fitness center services through different variables such as membership costs, opening hours, and aquatic services in fitness centers in the municipality of Madrid. 


\section{Materials and Methods}

The sample is composed of 193 fitness centers (179 private, 14 public) located in the city of Madrid, Spain, covering the 21 districts of the municipality (Figure 1). Madrid, located in the center of the Iberian Peninsula, is the capital city of Spain and has a population of almost 3.3 million inhabitants. Madrid has a land area over 600 square kilometers.

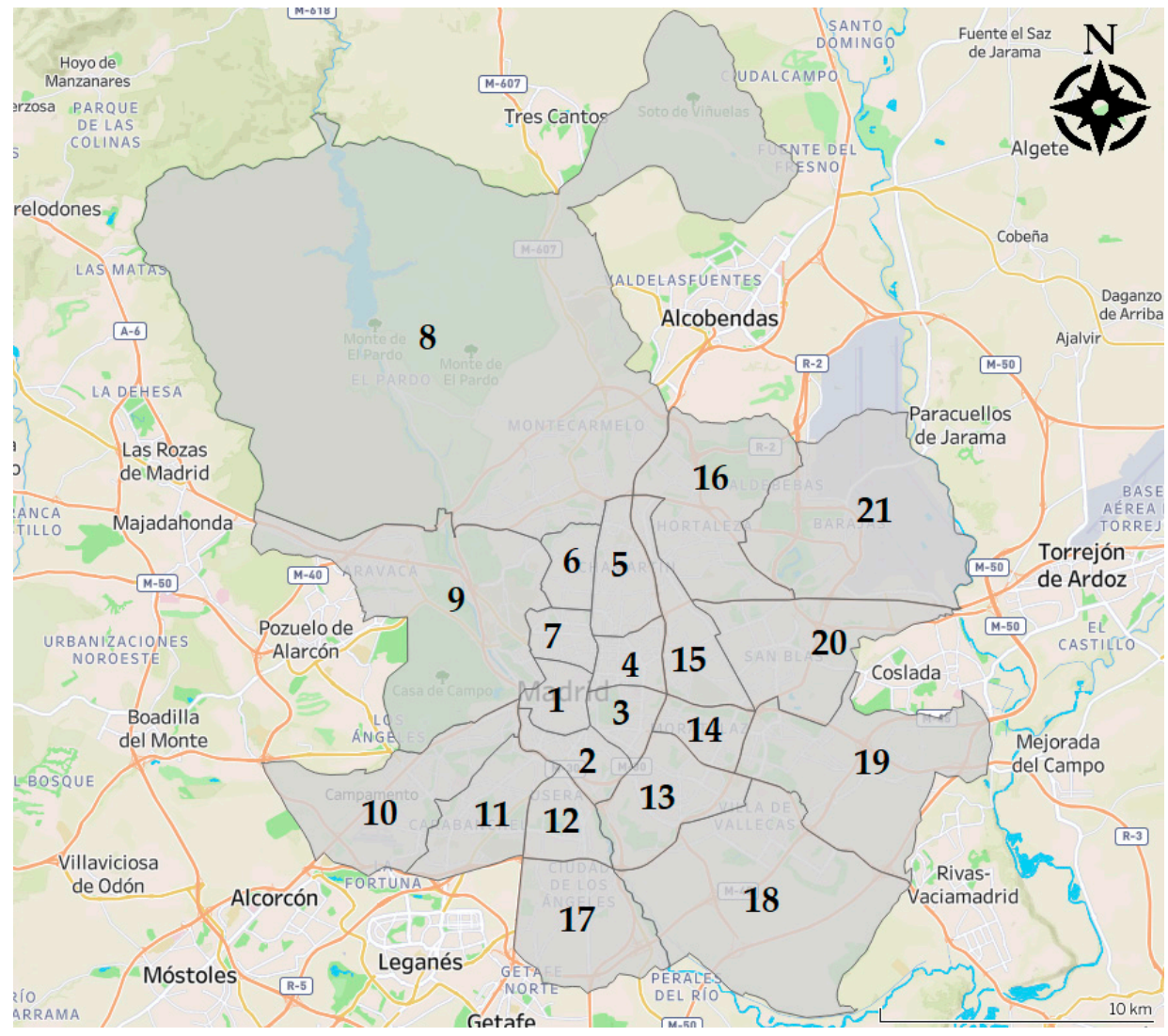

Figure 1. Districts in the city of Madrid: (1) Centro; (2) Arganzuela; (3) Retiro; (4) Salamanca; (5) Chamartín; (6) Tetuán; (7) Chamberí; (8) Fuencarral-El Pardo; (9) Moncloa-Aravaca; (10) Latina; (11) Carabanchel; (12) Usera; (13) Puente de Vallecas; (14) Moratalaz; (15) Ciudad Lineal; (16) Hortaleza; (17) Villaverde; (18) Villa de Vallecas; (19) Vicálvaro; (20) San Blas-Canillejas; (21) Barajas.

The selected fitness centers were retrieved from Madrid Council's Open Data Portal, which allows access to a complete database of the business census of the city. The June 2019 data package was used [33]. Several stages were addressed before reaching the final sample of 193 centers. Firstly, the complete business census was filtered by activity, obtaining the number of 730 sports centers, thus eliminating non-sports businesses. Secondly, those oriented to fitness activities were selected, as well as those currently inactive were deleted, obtaining 252 centers. Thirdly, for each of them, the monthly fee, business model (low-cost $\leq 30 €$; mid-market $=30 €-60 €$; premium $\geq 60 €$ ), and the existence or not of a swimming pool were checked. Any center with a lack of any of the aforementioned information was deleted from the database, resulting in a final number of 193 fitness centers. Lastly, the Walk Score ${ }^{\circledR}$ for each center location was manually derived from the website www.walkscore.com, using the exact address of the company [34].

For the analysis of the data, Walk Score ${ }^{\circledR}$ was used as a categorical variable, instead of continuous, as recommended by previous work [23,35]. Therefore, four quartiles were established $(\leq 90 ; 91-95$; 96-98; $\geq 99$ ). The data analysis was performed with IBM SPSS 23.0 Statistics software (IBM Inc., Chicago, IL, USA), including descriptive statistics, $t$-test, Mann-Whitney U test, and quadratic regression, as suggested in previous research $[14,23]$. The critical level of significance was set at $p<0.05$. 


\section{Results}

\subsection{Descriptive Statistics}

Data from 193 fitness centers were retrieved (Figure 2). A representative distribution in all the areas of the municipality was ensured, including centers in the 21 districts of the city of Madrid, Spain (Figure 3).

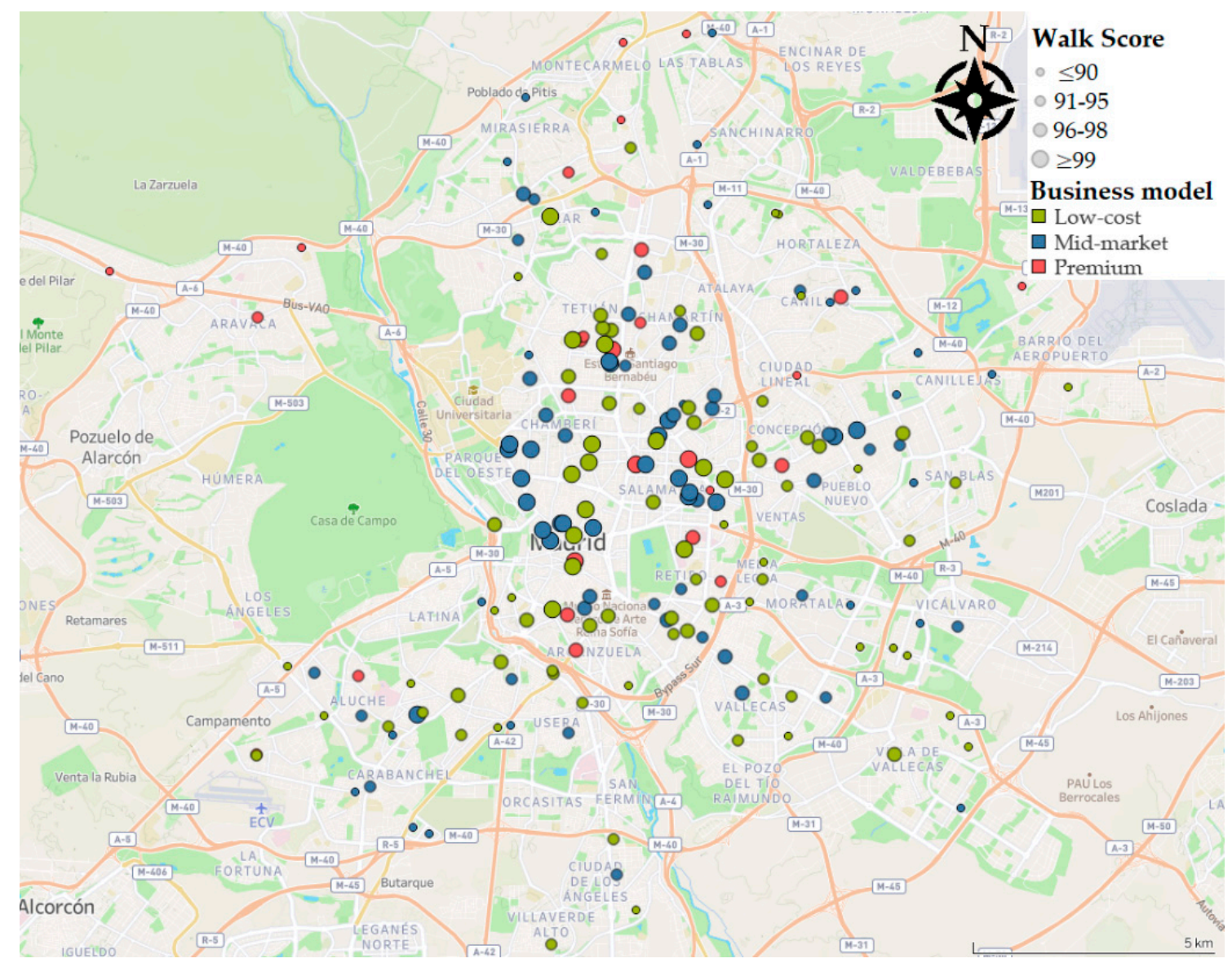

Figure 2. Distribution of the fitness centers in Madrid, sized by Walk Score ${ }^{\circledR}$.

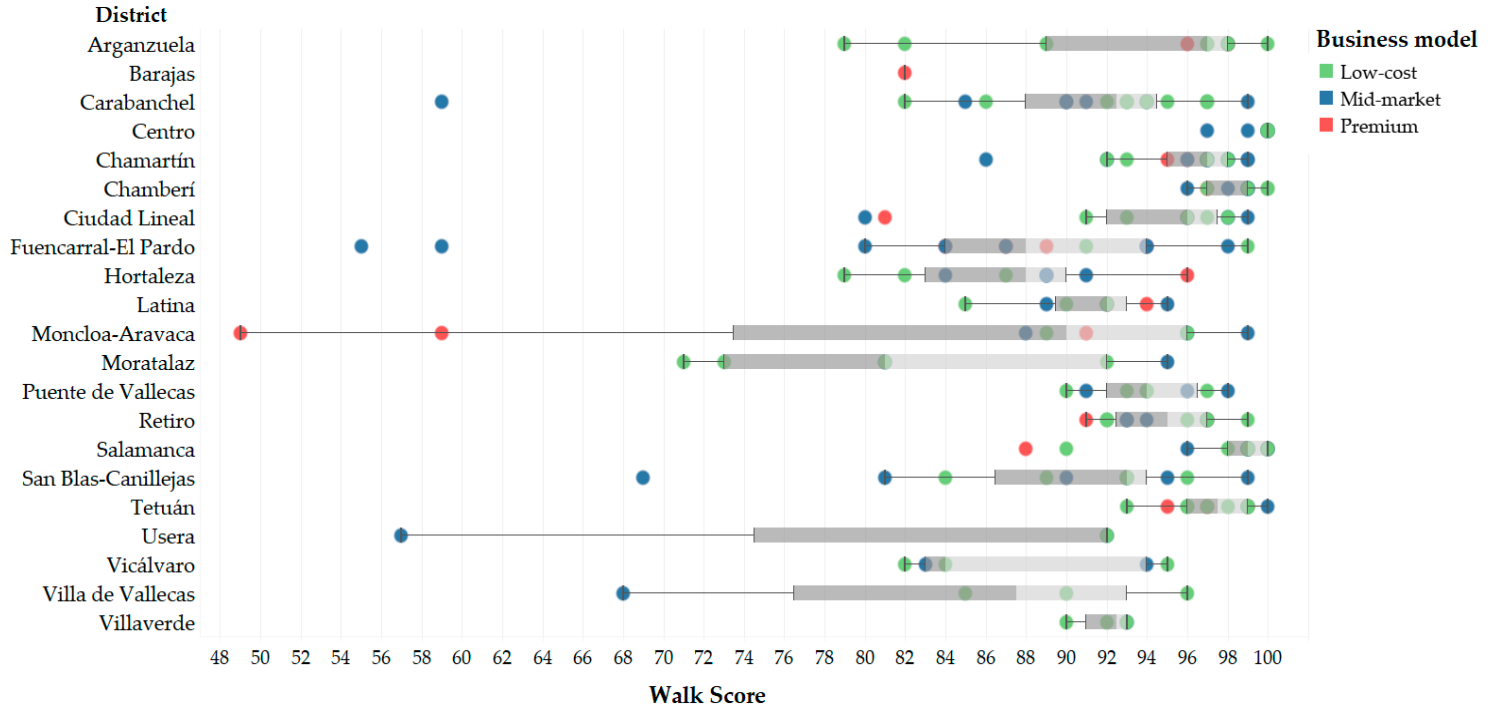

Figure 3. Fitness centers' distribution by district. 
Table 1 shows the means of Walk Score ${ }^{\circledR}$, monthly fee, and opening hours. These results are presented according to the business model (low-cost, mid-market, and premium). An average Walk Score ${ }^{\circledR}$ of $92.02(\mathrm{SD}=9.02)$ out of 100 was determined. The average fee per month was $41.46(\mathrm{SD}=28.70)$, and the average daily opening hours were $15.36(\mathrm{SD}=3.16)$. Additionally, $20.20 \%$ of the centers have a swimming pool.

Table 1. Descriptive statistics.

\begin{tabular}{ccccc}
\hline Variable & All Cases (SD) & Low-Cost $(\boldsymbol{n = 8 4 )}$ & Mid-Market $(\boldsymbol{n = 8 2 )}$ & Premium $(\boldsymbol{n}=\mathbf{2 7})$ \\
\hline Walk Score ${ }^{\circledR}$ & $92.02(9.02)$ & $92.71(6.35)$ & $91.82(10.26)$ & $90.44(11.83)$ \\
Monthly fee $(€)$ & $41.46(28.70)$ & $23.88(4.39)$ & $41.40(7.47)$ & $96.33(41.48)$ \\
Daily opening hours & $15.36(3.16)$ & $15.20(1.74)$ & $15.32(3.88)$ & $15.97(4.05)$ \\
\hline
\end{tabular}

\subsection{Association Between Walk Score ${ }^{\circledR}$ and the Monthly Fee}

A nonlinear relationship between Walk Score ${ }^{\circledR}$ and the monthly fee was obtained. According to the business model, no correlation was observed in either the low-cost or mid-market centers. Nevertheless, after measuring a normal distribution of data, the $t$-test only established statistically significant differences in premium centers, with lower fees in the range of 96-98 in contrast to a $\leq 90$ Walk Score ${ }^{\circledR}$ (Table 2). These data are presented graphically in Figure 4 . No statistically significant differences were observed between other Walk Score ${ }^{\circledR}$ ranges.

Table 2. Monthly fee $t$-test in premium centers according to Walk Score ${ }^{\circledR}$.

\begin{tabular}{cccc}
\hline Walk Score ${ }^{\circledR}$ & Average Monthly Fee (SD) & Difference & $p$-Value \\
\hline$\leq 90$ & $125.37(48.74)$ & 47.99 & 0.032 \\
$96-98$ & $77.38(25.19)$ & & \\
\hline
\end{tabular}

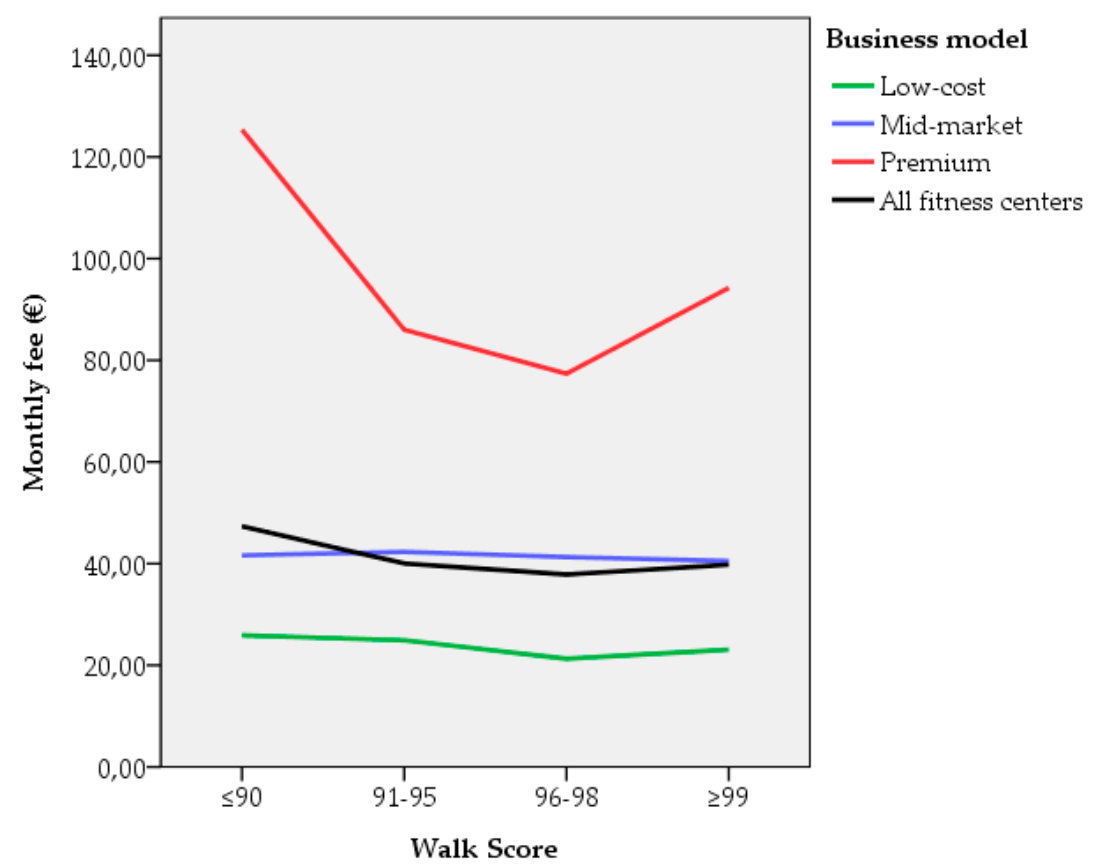

Figure 4. Monthly fee according to Walk Score ${ }^{\circledR}$.

A regression analysis of Walk Score ${ }^{\circledR}$ was conducted, following a curve estimation procedure. Different curves were estimated, namely, linear, quadratic, cubic, growth, and exponential. The quadratic model received the highest R-square (Table 3). Nevertheless, the analysis reveals a weak 
relationship between Walk Score ${ }^{\circledR}$ and the monthly fee $\left(R^{2}=0.05, F(2,190)=5.27, p=0.006\right)$. Therefore, medium levels of Walk Score ${ }^{\circledR}$ (96-98) weakly contribute to lower fees.

Table 3. Regression curve estimation.

\begin{tabular}{lcccccccc}
\hline \multirow{2}{*}{ Equation } & \multicolumn{4}{c}{ Model Summary } & \multicolumn{4}{c}{ Parameter Estimates } \\
\cline { 2 - 10 } & R-Square & F & df1 & df2 & Sig. & Constant & b1 & b2 \\
\hline Quadratic & 0.053 & 5.271 & 2 & 190 & 0.006 & 276.248 & -5.142 & 0.028 \\
\hline
\end{tabular}

\subsection{Association Between Walk Score ${ }^{\circledR}$ and Opening Hours}

The Mann-Whitney U test was performed to compare the average opening hours between the four Walk Score ${ }^{\circledR}$ groups (Table 4). The results show statistically significant differences between the ranges of $\leq 90$ and $96-98$, as well as between the groups of 91-95 and 96-98. Therefore, medium levels of Walk Score ${ }^{\circledR}$, specifically between 96 and 98 , are associated with wider opening hours.

Table 4. Opening hours comparison according to Walk Score ${ }^{\circledR}$ groups.

\begin{tabular}{cccc}
\hline Walk Score ${ }^{\circledR}$ & Average Opening Hours (SD) & Difference & $p$-Value \\
\hline$\leq 90$ & $14.88(3.14)$ & 0.83 & 0.036 \\
$96-98$ & $16.25(3.44)$ & 0.97 & 0.040 \\
\hline $91-95$ & $14.74(2.50)$ & & \\
$96-98$ & $16.25(3.44)$ & & \\
\hline
\end{tabular}

\subsection{Association Between Walk Score ${ }^{\circledR}$ and the Existence of a Swimming Pool}

The Mann-Whitney U test was also conducted to compare the average Walk Score ${ }^{\circledR}$ between fitness centers with a swimming pool and centers lacking a swimming pool. The results show statistically significant differences when comparing both clusters. Therefore, a lower Walk Score ${ }^{\circledR}$ is associated with swimming pools in the fitness centers (Table 5).

Table 5. Walk Score ${ }^{\circledR}$ comparison in fitness centers with and without a swimming pool.

\begin{tabular}{cccc}
\hline Swimming Pool & Average Walk Score ${ }^{\circledR}(\mathrm{SD})$ & Difference & $p$-Value \\
\hline No & $93.32(7.75)$ & 6.47 & 0.000 \\
Yes & $86.85(11.61)$ & & \\
\hline
\end{tabular}

\section{Discussion}

Walkability is an important concept in urban planning, with great implications for the population, since walkable places are usually related to economic performance, including real estate development and values as a result of their attractiveness to permanent and temporary populations $[7,36]$. This paper deals with an innovative approach for measuring the relationship between walkability and specific variables of fitness centers (price, opening hours, and aquatic services) as fundamental services for physical activity promotion, which help to improve citizens' health.

Firstly, regarding the association between Walk Score ${ }^{\circledR}$ and the monthly fee of fitness centers, a weak nonlinear relationship was observed, meaning that there is not a strong association between the two variables. These results show coherence with previous work on tourist attractions and walkability [14]. However, our results contrast with research on tourist accommodations. Although hotels and AirBnB locations also showed a nonlinear relationship, the range of 93-96 Walk Score ${ }^{\circledR}$ displays higher prices [23]. This weak link between walkability and price has implications for sports centers and other leisure-oriented businesses.

For the aforementioned reasons, there is no direct correlation between fitness centers with a higher Walk Score ${ }^{\circledR}$ and higher fees. Only in premium centers, a certain degree of association is proven. 
When analyzing premium centers, a quadratic equation curve fits in the model, as was presented in previous research [14]. Thus, fitness centers with higher fees are often located in less walkable locations. This circumstance may be related to the specific features of the fitness industry and the diverse business models, together with the preferences and needs of the users of sports centers, since as was observed in previous studies, price and location are among the criteria of greatest weight for users in Spain [37], the United States, and Canada [38]. Especially for fitness centers with a low-cost model, service convenience (where walkability would be integrated) is tightly related to user perceived quality, user satisfaction, and client loyalty [39]. In fact, regarding fitness centers and their locations, previous studies have shown that clients are willing to commit to even a $30 \mathrm{~min}$ commute time to the facility if the perceived quality is better [39], while a $15 \mathrm{~min}$ commute time positively influences the client's adherence to the center, leading to the client's involvement in a longer membership and longer member continuity $[37,40,41]$. This is especially important for increasing levels of physical activity and, subsequently, impacts citizens' health.

A good explanation for why users are willing to walk longer or to travel longer distances for premium services could be related to perceived service quality and added value. Previous studies have proven that the enjoyment of positive customer experience is associated with higher engagement levels, recommendation rates, and membership renewal intentions, with positive effects on all these variables [42-45]. For that reason, customers of premium fitness centers could be willing to walk longer distances or travel to less walk-friendly areas. This phenomenon has also been detected in the tourism sector $[2,46]$ since tourists are willing to walk longer distances to locations with a lower Walk Score ${ }^{\circledR}$ in order to enjoy the most popular tourist attractions.

Secondly, regarding the relationship between opening hours and Walk Score ${ }^{\circledR}$, our findings show that a moderate to high Walk Score ${ }^{\circledR}(96-98)$ correlates with longer opening hours. There is no direct correlation between fitness centers with a higher Walk Score ${ }^{\circledR}$ and wider opening hours. Good management practices encourage sport facilities managers to reinforce their company strengths [32]. Therefore, for fitness centers whose location is considered a strength, maximizing and enlarging opening hours contributes to maximizing this strength. Identical to the comparison between Walk Score ${ }^{\circledR}$ and price, low-cost centers need to pursue high service convenience, where opening hours may be influential, achieving ultimately a good perceived quality, user satisfaction, and client loyalty [38].

Lastly, regarding the relationship between the existence of a swimming pool at the gyms and Walk Score ${ }^{\circledR}$, our findings show that a lower Walk Score ${ }^{\circledR}$ correlates with the existence of aquatic services. In this regard, the ability to enjoy guided and free aquatic physical activities is an attractive aspect for gym users, especially affecting client satisfaction in the case of group class swimmers and future intentions in the case of free swimming users [47]. It has been shown that a swimming pool is not considered essential, but influential and attractive for customers at the moment of gym enrolment, even if swimming pool use rates are low [37]. However, the swimming pool is not always a profitable space, especially for fitness centers whose main focus is not related to aquatic activities [40]; therefore, gyms located in better locations (i.e., with a more expensive rental or surface fee) prefer not to dedicate a big surface area to these aquatic services.

\section{Conclusions}

This paper contributes to understanding the association between the geographical distribution of fitness centers and the variables of price, opening hours, and aquatic services. Firstly, no direct correlation is shown between Walk Score ${ }^{\circledR}$ and monthly fee. A weak quadratic model is followed only by premium centers, with higher prices in less walkable areas, meaning that members of these centers are willing to travel to less walk-friendly areas. Secondly, the association between Walk Score ${ }^{\circledR}$ and opening hours is not totally confirmed. Fitness centers in moderately to highly walkable locations tend to widen their average hours of operation, but there is not a direct correlation. Thirdly, the existence of a swimming pool is associated with a lower Walk Score ${ }^{\circledR}$. In this regard, fitness centers in less walkable areas try to offer additional services such as aquatic services to differentiate themselves from 
better located competitors. However, centers in walkable locations do not need to invest in swimming pools and prefer to use this area for other purposes. All these data are relevant for increasing the adherence to fitness services. A better tailored experience would help to promote physical activity services participation and engagement.

This research has clear practical implications, mainly for managers of sports services. Business location is particularly important for increasing levels of adherence to fitness centers, helping to increase levels of physical activity. Understanding the geographical distribution of fitness centers would help them to tailor the offer to potential customers. Walk Score ${ }^{\circledR}$ can be a useful open resource for managers of sports services at the time of deciding the best location and fitness center characteristics.

However, this work deals with the limitation of the local features of the municipality of Madrid. The urban distribution of Madrid shares many characteristics with other European capitals. However, our conclusions could be limited by specific local conditions and particular issues of Madrid. Nevertheless, there is no evidence in recent previous literature [19-21] to believe that Walk Score ${ }^{\circledR}$ substantially differs outside the United States, mainly in high population density areas. Despite the applied approach, we recognize that there are other approaches, especially regarding spacial autocorrelation. Future studies should address different cities for further examination of fitness center parameters' geographical distribution. Additionally, more extensive areas could be assessed, including both urban and rural spaces.

Author Contributions: Conceptualization, J.L.-Q.; Data curation, J.L.-Q. and P.B.; Formal analysis, J.L.-Q. and J.B.; Methodology J.L.-Q. and Á.F.-L.; Writing—original draft preparation, J.L.-Q., J.B., and Á.F.-L.; Writing—review and editing, P.B. and Á.F.-L. All authors have read and agreed to the published version of the manuscript.

Funding: This research received no external funding.

Conflicts of Interest: The authors declare no conflict of interest.

\section{References}

1. Wang, H.; Yang, Y. Neighbourhood walkability: A review and bibliometric analysis. Cities 2019, 93, 43-61.

2. Hall, C.M.; Ram, Y. Walk score ${ }^{\circledR}$ and its potential contribution to the study of active transport and walkability: A critical and systematic review. Transp. Res. Part D Transp. Environ. 2018, 61, 310-324. [CrossRef]

3. Doyle, S.; Kelly-Schwartz, A.; Schlossberg, M.; Stockard, J. Active Community Environments and Health: The Relationship of Walkable and Safe Communities to Individual Health. J. Am. Plan. Assoc. 2006, 72, 19-31.

4. Van Cauwenberg, J.; Van Holle, V.; De Bourdeaudhuij, I.; Van Dyck, D.; Deforche, B. Neighborhood walkability and health outcomes among older adults: The mediating role of physical activity. Heal. Place 2016, 37, 16-25.

5. Southworth, M. Designing the Walkable City. J. Urban Plan. Dev. 2005, 131, 246-257. [CrossRef]

6. Corti, B.; Wood, G.; Pikora, T.; Learnihan, V.; Bulsara, M.; Van Niel, K.; Timperio, A.; McCormack, G.; Villanueva, K. School site and the potential to walk to school: The impact of street connectivity and traffic exposure in school neighborhoods. Heal. Place 2011, 17, 545-550.

7. Leinberger, C.B.; Alfonzo, M. Walk This Way: The Economic Promise of Walkable Places in Metropolitan Washington, D.C.; The Brookings Institution: Washington, DC, USA, 2012.

8. Rafiemanzelat, R.; Emadi, M.I.; Kamali, A.J. City sustainability: The influence of walkability on built environments. Transp. Res. Procedia 2017, 24, 97-104.

9. Lytras, M.D.; Visvizi, A. Who Uses Smart City Services and What to Make of It: Toward Interdisciplinary Smart Cities Research. Sustainability 2018, 10, 1998. [CrossRef]

10. Yeh, H. The effects of successful ICT-based smart city services: From citizens' perspectives. Gov. Inf. Q. 2017, $34,556-565$.

11. O'Donoghue, G.; Perchoux, C.; Mensah, K.; Lakerveld, J.; van der Ploeg, H.; Bernaards, C.; Chastin, S.F.M.; Simon, C.; O'Gorman, D.; Nazare, J.A. A systematic review of correlates of sedentary behaviour in adults aged 18-65 years: A socio-ecological approach. BMC Public Health 2016, 16, 163.

12. Rhodes, R.; Mark, R.S.; Temmel, C.P. Adult Sedentary Behavior. Am. J. Prev. Med. 2012, 42, e3-e28. [CrossRef] [PubMed] 
13. Forsyth, A. What is a walkable place? The walkability debate in urban design. Urban Des. Int. 2015, 20, 274-292. [CrossRef]

14. Hall, C.M.; Ram, Y. Measuring the relationship between tourism and walkability? Walk Score and English tourist attractions. J. Sustain. Tour. 2018, 27, 223-240.

15. Vale, D.; Saraiva, M.; Pereira, M. Active accessibility: A review of operational measures of walking and cycling accessibility. J. Transp. Land Use 2015, 9, 209-235.

16. Fitzgerald, M.; Pasha, A. Google Ajax Search API; O’Reilly Media, Inc.: Sebastopol, CA, USA, 2007.

17. Carr, L.J.; Dunsiger, S.I.; Marcus, B.H. Walk ScoreTM as a Global Estimate of Neighborhood Walkability. Am. J. Prev. Med. 2010, 39, 460-463. [CrossRef]

18. Carr, L.; Dunsiger, S.I.; Marcus, B.H. Validation of Walk Score for estimating access to walkable amenities. Br. J. Sports Med. 2010, 45, 1144-1148. [CrossRef]

19. Duncan, D.T.; Aldstadt, J.; Whalen, J.; Melly, S.J.; Gortmaker, S.L. Validation of Walk Score®for Estimating Neighborhood Walkability: An Analysis of Four US Metropolitan Areas. Int. J. Environ. Res. Public Heal. 2011, 8, 4160-4179. [CrossRef]

20. Duncan, D.T.; Meline, J.; Kestens, Y.; Day, K.; Elbel, B.; Trasande, L.; Chaix, B. Walk Score, Transportation Mode Choice, and Walking Among French Adults: A GPS, Accelerometer, and Mobility Survey Study. Int. J. Environ. Res. Public Heal. 2016, 13, 611. [CrossRef]

21. Meline, J.; Chaix, B.; Pannier, B.; Ogedegbe, G.; Trasande, L.; Athens, J.K.; Duncan, D.T. Neighborhood walk score and selected Cardiometabolic factors in the French RECORD cohort study. BMC Public Heal. 2017, $17,960$.

22. Koohsari, M.J.; Sugiyama, T.; Hanibuchi, T.; Shibata, A.; Ishii, K.; Liao, Y.; Oka, K. Validity of Walk Scoreßas a measure of neighborhood walkability in Japan. Prev. Med. Rep. 2018, 9, 114-117. [CrossRef]

23. Ram, Y.; Hall, C.M. Walk Score and tourist accommodation. Int. J. Tour. Cities 2018, 4, 369-375. [CrossRef]

24. Simbaqueba, J. What Does Walk Score ${ }^{\circledR}$ Really Measure? Master's Thesis, University of Connecticut, Mansfield, CT, USA, 2018.

25. Lo, B.K.; Graham, M.L.; Folta, S.C.; Paul, L.C.; Strogatz, D.; Nelson, M.E.; Parry, S.; Carfagno, M.E.; Wing, D.; Higgins, M.; et al. Examining the Associations between Walk Score, Perceived Built Environment, and Physical Activity Behaviors among Women Participating in a Community-Randomized Lifestyle Change Intervention Trial: Strong Hearts, Healthy Communities. Int. J. Environ. Res. Public Heal. 2019, 16, 849. [CrossRef] [PubMed]

26. Loo, C.K.J.; Greiver, M.; Aliarzadeh, B.; Lewis, D. Association between neighbourhood walkability and metabolic risk factors influenced by physical activity: A cross-sectional study of adults in Toronto, Canada. BMJ Open 2017, 7, e013889. [CrossRef] [PubMed]

27. Orychock, K.; Fuller, D. Association between BMI and WalkScore, Dining and Drinking Score, Grocery Score and Transit Score in a multi-city sample of adults: A cross-sectional analysis. In Proceedings of the APHA's 2019 Annual Meeting and Expo, Philadelphia, PA, USA, 2-6 November 2019.

28. Howe, K.B.; Suharlim, C.; Ueda, P.; Howe, D.; Kawachi, I.; Rimm, E.B. Gotta catch'em all! Pokémon GO and physical activity among young adults: Difference in differences study. BMJ 2016, 355, i6270. [CrossRef] [PubMed]

29. Cheung, R.; Woo, M. Determinants of Perceived Service Quality: An Empirical Investigation of Fitness and Recreational Facilities. Contemp. Manag. Res. 2016, 12, 363-370. [CrossRef]

30. Emeterio, I.C.S.; Garcia-Unanue, J.; Iglesias-Soler, E.; Felipe, J.; Gallardo, L. Prediction of abandonment in Spanish fitness centres. Eur. J. Sport Sci. 2018, 19, 217-224. [CrossRef]

31. García-Fernández, J.; Gálvez-Ruiz, P.; Velez-Colon, L.; Bernal-Garcia, A. Service convenience, perceived value, satisfaction, and loyalty: A study of consumers from low-cost fitness centers in Spain. J. Phys. Educ. Sport 2016, 16, 1146-1152.

32. León-Quismondo, J.; Garcia-Unanue, J.; Burillo, P. Best Practices for Fitness Center Business Sustainability: A Qualitative Vision. Sustainability 2020, 12, 5067. [CrossRef]

33. Madrid Council's Open Data Portal. Censo de locales, sus actividades y terrazas de hostelería y restauración. Available online: https://datos.madrid.es/sites/v/index.jsp?vgnextoid=66665cde99be2410VgnVCM1000000 b205a0aRCRD\&vgnextchannel=374512b9ace9f310VgnVCM100000171f5a0aRCRD (accessed on 11 May 2018).

34. Walk Score ${ }^{\circledR}$. Available online: https://www.walkscore.com/ (accessed on 20 May 2020). 
35. Li, W.; Joh, K.; Lee, C.; Kim, J.-H.; Park, H.; Woo, A. Assessing Benefits of Neighborhood Walkability to Single-Family Property Values. J. Plan. Educ. Res. 2015, 35, 471-488. [CrossRef]

36. Trowbridge, M.J.; Pickell, S.G.; Pyke, C.R.; Jutte, D.P. Building Healthy Communities: Establishing Health And Wellness Metrics For Use Within The Real Estate Industry. Heal. Aff. 2014, 33, 1923-1929. [CrossRef]

37. León-Quismondo, J.; García-Unanue, J.; Burillo, P. Priorities in the management of fitness centers. Application of Importance-Performance Analysis. J. Sports Econ. Manag. 2018, 8, 116-136.

38. Heroux, L. Comparative Marketing Strategies of Fitness Clubs in the United States and Canada. Econ. World 2017, 5, 529-538.

39. García-Fernández, J.; Gálvez-Ruíz, P.; Fernández-Gavira, J.; Vélez-Colón, L.; Pitts, B.; Bernal-García, A. The effects of service convenience and perceived quality on perceived value, satisfaction and loyalty in low-cost fitness centers. Sport Manag. Rev. 2018, 21, 250-262. [CrossRef]

40. León-Quismondo, J.; Garcia-Unanue, J.; Burillo, P. Service Perceptions in Fitness Centers: IPA Approach by Gender and Age. Int. J. Environ. Res. Public Heal. 2020, 17, 2844. [CrossRef] [PubMed]

41. García-Fernández, J.; Gálvez-Ruíz, P.; Fernández-Gavira, J.; Vélez-Colón, L. A loyalty model according to membership longevity of low-cost fitness center: Quality, value, satisfaction, and behavioral intention. Revista de Psicología del Deporte 2016, 25, 107-110.

42. Afthinos, Y.; Theodorakis, N.D.; Nassis, P. Customers' expectations of service in Greek fitness centers. Manag. Serv. Qual. Int. J. 2005, 15, 245-258. [CrossRef]

43. Alexandris, K.; Zahariadis, P.; Tsorbatzoudis, C.; Grouios, G. An empirical investigation of the relationships among service quality, customer satisfaction and psychological commitment in a health club context. Eur. Sport Manag. Q. 2004, 4, 36-52. [CrossRef]

44. Avourdiadou, S.; Theodorakis, N.D. The development of loyalty among novice and experienced customers of sport and fitness centres. Sport Manag. Rev. 2014, 17, 419-431. [CrossRef]

45. MacIntosh, E.; Law, B. Should I stay or should I go? Exploring the decision to join, maintain, or cancel a fitness membership. Manag. Sport Leis. 2015, 20, 191-210. [CrossRef]

46. Hall, C.M.; Ram, Y.; Shoval, N. The Routledge International Handbook of Walking; Routledge: London, UK, 2017, ISBN 9781315638461.

47. Prado-Gascó, V.; Calabuig, F.; Crespo, J.; Nuñez-Pomar, J. Satisfaction of users of aquatic activities: Free swimming vs. guided activities. J. Phys. Educ. Sport 2018, 18, 1247-1434.

(C) 2020 by the authors. Licensee MDPI, Basel, Switzerland. This article is an open access article distributed under the terms and conditions of the Creative Commons Attribution (CC BY) license (http://creativecommons.org/licenses/by/4.0/). 